\title{
Abscisic acid and the antioxidant system are involved in germination of Butia capitata seeds
}

\author{
Elisa Monteze Bicalho* (1), Talita R. Silva dos Santos ${ }^{1}$ (I) and Queila Souza Garcia ${ }^{1}$ (1)
}

Received: May 29, 2018

Accepted: August 16, 2018

\begin{abstract}
Seed germination is an important step for plants without vegetative propagation and is a physiological process that begins with specific environmental cues resulting in biochemical responses. Breaking-dormancy is necessary to study germination in dormant seeds with asynchronous germination. We investigated the processes of breaking dormancy and germination of Butia capitata (Arecaceae) seeds, in which germination is slow and asynchronous, by operculum removal. This treatment increased germination of B. capitata to $90 \%$. Embryos of dry, imbibed, 24-hours post-operculum removal and early-germinated seeds were collected for biochemical analysis of the following: quantification of abscisic acid (ABA) and hydrogen peroxide $\left(\mathrm{H}_{2} \mathrm{O}_{2}\right)$, activities of antioxidant enzymes (catalase - CAT, superoxide dismutase - SOD, glutathione reductase - GR) and histolocalization of superoxide anion $\left(\mathrm{O}_{2}{ }^{-}\right)$. Decreases in $\mathrm{H}_{2} \mathrm{O}_{2}$ and $\mathrm{ABA}$ were recorded 24 hours post-operculum removal. Increased GR and SOD activities during imbibition, and CAT upon germination, indicate a role in controlling reactive oxygen species. Interestingly, the accumulation of $\mathrm{O}_{2}$ - on the haustorium upon imbibition seems to be involved in germination, instead of $\mathrm{H}_{2} \mathrm{O}_{2}$. For B. capitata seeds, signaling from the removal of the operculum probably resulted in ABA catabolism mediated by $\mathrm{O}_{2}^{-}$, which thus promoted seed germination.
\end{abstract}

Keywords: breaking-dormancy, haustorium, hormones, palm seeds, operculum, physiological dormancy, reactive oxygen species

Seed germination is one of the most important processes in the life cycle of a plant, and its success depends on environmental conditions and appropriate physiological and biochemical responses (Bewley et al. 2013). Reactive oxygen species (ROS) are continuously produced in metabolically active cells of seeds (Gomes \& Garcia 2013). During metabolic recovery following imbibition, ROS production increases as germination progresses (Bailly 2004). The production of ROS stimulates the antioxidant system to scavenge toxic levels of those same chemicals as they interact with phytohormones and germination signaling pathways (Diaz-Vivancos et al. 2013). Reactive oxygen species, especially hydrogen peroxide $\left(\mathrm{H}_{2} \mathrm{O}_{2}\right)$, are known to be involved in gibberellin (GA) biosynthesis and abscisic acid (ABA) catabolism during germination (Liu et al. 2010; Gomes \& Garcia 2013). The balance between these two phytohormones induces germination or the maintenance of dormancy (Bicalho et al. 2015; Vieira et al. 2017). 
Palms (Arecaceae) are restricted to the tropics (Tomlinson 2006), but can be found in varying environments (Svenning 2001) with many species producing seeds with primary dormancy and very slow seedling recruitment over time (Pérez et al. 2008; Baskin \& Baskin 2013; Bicalho et al. 2015). In the cerrado (Brazilian savanna), there are interesting and useful palm species that contribute to the survival and development of local communities. One such palm is Butia capitata (Mart.) Becc., popularly known as coquinho-azedo, which naturally occurs in environments with seasonal water deficit and whose fruits are used as food. The germination of $B$. capitata seeds is considered slow and asynchronous due to the physiological, or morphophysiological (see Baskin \& Baskin 2014), dormancy of this species, which is related to the difficulty the embryo has in overcoming restrictions imposed by adjacent tissues (Oliveira et al. 2013). Overexploitation and slow natural regeneration by seeds call for conservation efforts regarding the species. However, the physiological changes, as well as the underlying signaling, involved in the process of seed germination of B. capitata are not well understood.

We thus performed an experiment to better understand the relationship between abscisic acid (ABA), ROS and the antioxidant system of $B$. capitata embryos during germination. To facilitate the experiment and to optimize the synchrony of germination, we employed operculum removal for overcoming dormancy since this method is known to significantly increase germination of palm species (Spera et al. 2001; Fior et al. 2011; Oliveira et al. 2013; Bicalho et al. 2016). The operculum comprises the region with micropilar endosperm and the tegument that is pushed by the embryo during natural germination. However, the natural removal of the operculum by the embryo (visible germination) in B. capitata (and other palm species, see Segovia et al. 2003, and Bicalho et al. 2015) is very slow and asynchronous (Oliveira et al. 2013), which would make the present experiment impracticable. Artificial removal of the operculum exposes the embryo to the environment, which may trigger some kind of signaling, but information regarding this is scarce. Thus, our main objective was to better understand the dynamics of ABA and ROS following operculum removal that leads to germination.

Fruits of B. capitata were collected in the municipality of Mirabela, state of Minas Gerais. The region is tropical with hot summers and very dry winters; the mean annual precipitation is approximately $900 \mathrm{~mm}$ with a seasonal water deficit, and the mean annual temperature is $22^{\circ} \mathrm{C}$ with a thermal range of approximately $15^{\circ} \mathrm{C}$ ( $\mathrm{C}$ wa by the Köppen system) (Köppen 1900; Alvares et al. 2013).

Approximately 4000 B. capitata fruits were collected from at least 100 trees. Four replicates of 15 seeds were sowed in distilled water and used to determine imbibition time by weighing the seeds daily until they reached a constant weight. Four replicates of 25 seeds were used for preliminary germination experiments. These seeds were surface sterilized with $5 \% \mathrm{NaClO}$ for 15 minutes and then rinsed three times with distilled water. The seeds were then held in distilled water for three days and subsequently transferred to transparent germination boxes lined with a double layer of filter paper moistened with distilled water, which were kept in a germination chamber at $30{ }^{\circ} \mathrm{C}$ for 30 days under a $12 \mathrm{~h}$ - photoperiod (Phillips, $40 \mu \mathrm{mol}$ photons $\mathrm{m}^{-2} \mathrm{~s}^{-1}$ ).

The opercula of the seeds were removed three days after immersion in distilled water (when imbibition stabilized). After this dormancy-breaking treatment, the germination experiment was carried out in the germination chambers as previously described with germination percentages being evaluated daily. The criterion used for visible germination was the protrusion of the cotyledonary petiole.

Embryos were extracted from seeds at different phases of the germination process: pre-imbibition ( $D$, dry), postimbibition (I), 24 hours after operculum removal (24 h), and early germination ( $\mathrm{G}$, visible germination). The sampled embryos were used for the following biochemical analyses: quantification of $\mathrm{ABA}$ and $\mathrm{H}_{2} \mathrm{O}_{2}$; enzymatic activity of catalase (CAT), superoxide dismutase (SOD), glutathione reductase (GR); and localization of superoxide anion $\mathrm{O}_{2}{ }^{-}$. Germination phases were independently sampled with the samples consisting of four replicates of 200 embryos.

Abscisic acid extraction was performed following Weiler (1980), with some modifications. Four replicates of $100 \mathrm{mg}$ of embryos were powdered using a mortar and pestle with liquid nitrogen and then homogenized in $80 \%$ methanol with $0.5 \mathrm{mg} \mathrm{mL}^{-1}$ ascorbic acid and $10 \mathrm{mg} \mathrm{L}^{-1}$ BHT. The samples were then added to $\mathrm{pH} 7.0$ TBS buffer with the resulting solution reaching less than $10 \%$ organic solvents. Quantification of ABA (controls, standard curve, samples and calculations) was performed strictly following the recommendations of Phytodetek ${ }^{\circledR}$ ABA Test Kits (Agdia Incorporated, Indiana, USA). Since water content increased throughout imbibition, the values of ABA quantification obtained for I, $24 \mathrm{~h}$ and $\mathrm{G}$ phases were corrected based on $\mathrm{D}$ phase moisture content.

Quantification of $\mathrm{H}_{2} \mathrm{O}_{2}$ was performed following Velikova et al. (2000). Four replicates of $100 \mathrm{mg}$ of embryos were powdered using a mortar and pestle with liquid nitrogen, homogenized with $0.1 \%$ trichloroacetic acid (TCA), and centrifuged at $12000 \mathrm{~g}$ for 15 minutes. The extract was reacted with $10 \mathrm{mM}$ of $\mathrm{pH} 7.0$ phosphate buffer and 1 $\mathrm{M} \mathrm{KI}$. The absorbance was recorded at $390 \mathrm{~nm}$ and the $\mathrm{H}_{2} \mathrm{O}_{2}$ content subsequently calculated from the standard curve. The values of $\mathrm{H}_{2} \mathrm{O}_{2}$ were also corrected as for ABA quantification.

Antioxidant enzyme extract was prepared following Gomes et al. (2013). Four replicates of $100 \mathrm{mg}$ of embryos were pulverized in liquid nitrogen and homogenized in $100 \mathrm{mM}$ of pH 7.8 phosphate buffer with $100 \mathrm{mM}$ EDTA and $5 \%$ PVP. The extract was then centrifuged at $12000 \mathrm{~g}\left(4{ }^{\circ} \mathrm{C}\right)$ 
and subsequently used to evaluate enzymatic activity and protein content, the latter using Bradford's method (Bradford 1976).

Catalase activity was determined following Aebi (1984) in $67 \mathrm{mM}$ phosphate buffer (pH 7.0) with $10 \mathrm{mM}$ $\mathrm{H}_{2} \mathrm{O}_{2}$ and adequate amounts of the enzyme extract. Consumption of $\mathrm{H}_{2} \mathrm{O}_{2}$ was recorded at $240 \mathrm{~nm}$ for 2 minutes $\left(\mathcal{E}=0.0394 \mathrm{mM}^{-1} \mathrm{~cm}^{-1}\right)$. Superoxide dismutase activity was determined in a reaction buffer containing $50 \mathrm{mM}$ phosphate buffer ( $\mathrm{pH}$ 7.8), $13 \mathrm{mM}$ L-methionine, $0.1 \mathrm{mM}$ EDTA, $0.002 \mathrm{mM}$ riboflavin, and $0.075 \mathrm{mM}$ nitroblue tetrazolium (NBT) (Giannopolitis \& Ries 1977). Blue formazan concentrations were read at $575 \mathrm{~nm}$, and one unit of SOD was considered as the amount of enzyme necessary to reduce $50 \%$ of the $\mathrm{O}_{2}$. Glutathione reductase activity was determined in media containing $100 \mathrm{mM}$ phosphate buffer (pH 7.8), $50 \mathrm{mM}$ oxidized glutathione, $5 \mathrm{mM} \mathrm{NADPH}$, and adequate amounts of the enzymatic extract, with NADPH oxidation being monitored at $340 \mathrm{~nm}\left(\varepsilon=6.2 \mathrm{mM}^{-1} \mathrm{~cm}^{-1}\right)$ (Foyer \& Halliwell 1976).

Histolocalization of superoxide anion $\left(\mathrm{O}_{2}{ }^{-}\right)$was performed strictly following Oracz et al. (2012). Twenty embryos of each phase were immersed in $10 \mathrm{mM}$ of TRIS buffer ( $\mathrm{pH}$ 7.0) with $1 \mathrm{mM}$ of a nitroblue tetrazolium (NBT) solution for 10 minutes. The embryos were then washed three times in $10 \mathrm{mM}$ TRIS buffer ( $\mathrm{pH}$ 7.0) and photographed.

The data for $\mathrm{ABA}, \mathrm{H}_{2} \mathrm{O}_{2}$ and antioxidant enzyme activities were tested for normality and homoscedasticity using Cochran and Levene's test, respectively. Normal and homoscedastic or transformed data (arcsine root square) were analyzed by ANOVA followed by the Tukey test for comparisons of all means at $5 \%$ level of probability, using Statistica 7 StatSoft ${ }^{\circledR}$ software.

The germination of B. capitata seeds was $88 \%$ at $72 \mathrm{~h}$ post-operculum removal (Fig. 1A) with great concentrations of ABA prior to imbibition (Fig. 1B). Biosynthesis of ABA has been shown to be a response to water deficit (Bray 1997), a common condition in plants growing in localities with well-defined dry seasons (Liu et al. 2005), as is the case for B. capitata. The initially high levels of ABA observed for B. capitata embryos reduced during imbibition (Fig. 1B). Reductions in ABA levels during imbibition were also observed by Bicalho et al. (2015) for macaw palm embryos, and by Dias et al. (2017) in the cotyledonary petiole of B. capitata seeds, both of which were related to leakage. In this work the reduction in $\mathrm{H}_{2} \mathrm{O}_{2}$ levels was found only $24 \mathrm{~h}$ after operculum removal (Fig. 1C) and the presence of $\mathrm{H}_{2} \mathrm{O}_{2}$ has been shown to induce ABA catabolism in pea seeds, thereby allowing germination (Barba-Espin et al. 2010). It is interesting to point out that in the present work $A B A$ levels decreased continuously from I to early-germination phase (Fig. 1B). Concentrations of $\mathrm{H}_{2} \mathrm{O}_{2}$ were also observed to be maintained in the early-germination phase relative to $24 \mathrm{~h}$ post-operculum removal (Fig. 1C).
As shown by purple coloration indicating a positive reaction with $\mathrm{NBT}, \mathrm{O}_{2}^{-}$was intensely produced in the haustorium region of $B$. capitata embryos since imbibition (Fig. 2). Interestingly, the presence of $\mathrm{O}_{2}^{-}$was indicated only in haustorium region, which is rich in reserves for early seedling growth. These results suggest that the haustorium has actions that go beyond reserve mobilization beginning with the first events of imbibition (see the increasing color intensity from $D$ to $G$ embryos of B. capitata; Fig. 2). The haustorium can also be assumed to play a role as a source of signaling mediated by $\mathrm{O}_{2}{ }^{-}$formation. An interesting relationship was observed here between $A B A$ and ROS: reductions of both $\mathrm{ABA}$ and $\mathrm{H}_{2} \mathrm{O}_{2}$ levels following operculum removal (Fig. 1B), with an increase in $\mathrm{O}_{2}$ - formation (Fig. 2). These results indicate that the dynamics of ROS and $A B A$ are related to operculum removal. This leads to the suggestion that the exposure of the embryo to $\mathrm{O}_{2}$ due to operculum removal (dormancy-breaking process) induced metabolic changes in hormonal and oxidant components. Reductions in $\mathrm{H}_{2} \mathrm{O}_{2}$ levels and increasing $\mathrm{O}_{2}{ }^{-}$formation in embryos of after operculum removal have also been observed in other palm species (TRS Santos unpubl. res.). The formation of ROS during germination is a natural process due to the reactivation of metabolism and increased respiration (Diaz-Vivancos et al. 2013), and can serve as a window of signaling, or the cause of damage if overproduced (ElMaarouf-Bouteau \& Bailly 2008). Therefore, the activity of antioxidant enzymes during germination of $B$. capitata seeds was investigated.

Among the enzymes investigated here, SOD and GR were observed to have increased activity relative to D seeds as soon as imbibition occurred (Fig. 1E, F), while CAT activity was higher in the early-germination phase than in phases I and $24 \mathrm{~h}$ post-operculum removal $(P<0.05$; Fig. 1D). The SOD and GR results indicate that imbibition in B. capitata seeds seems to induce or stimulate the activity of antioxidant enzymes. Indeed, that imbibition leads to increased respiration metabolism, which generates ROS and stimulates antioxidant pathways to keep redox homeostasis under control, has been widely discussed (Foyer \& Noctor 2005; El-Maarouf-Bouteau \& Bailly 2008; Diaz-Vivancos et al. 2013; Gomes \& Garcia 2013). It is important to point out that CAT activity was at least 10fold higher than that of SOD (Fig. 1D, E), suggesting that $\mathrm{H}_{2} \mathrm{O}_{2}$ was maintained at non-toxic levels in germinating seeds (higher CAT activity). Another interesting observation is that the increased SOD activity upon imbibition did not eliminate $\mathrm{O}_{2}^{-}$, which leads to the conclusion that the presence of this molecule is essential for the process of seed germination. Moreover, since $\mathrm{O}_{2}{ }^{-}$is present only in the haustorium, it participates in germination itself and not only in reserve mobilization (a post-germinative event). Altogether, as germination of $B$. capitata seeds progresses successfully, the activities of CAT, SOD and GR can be assured and are essential for keeping 

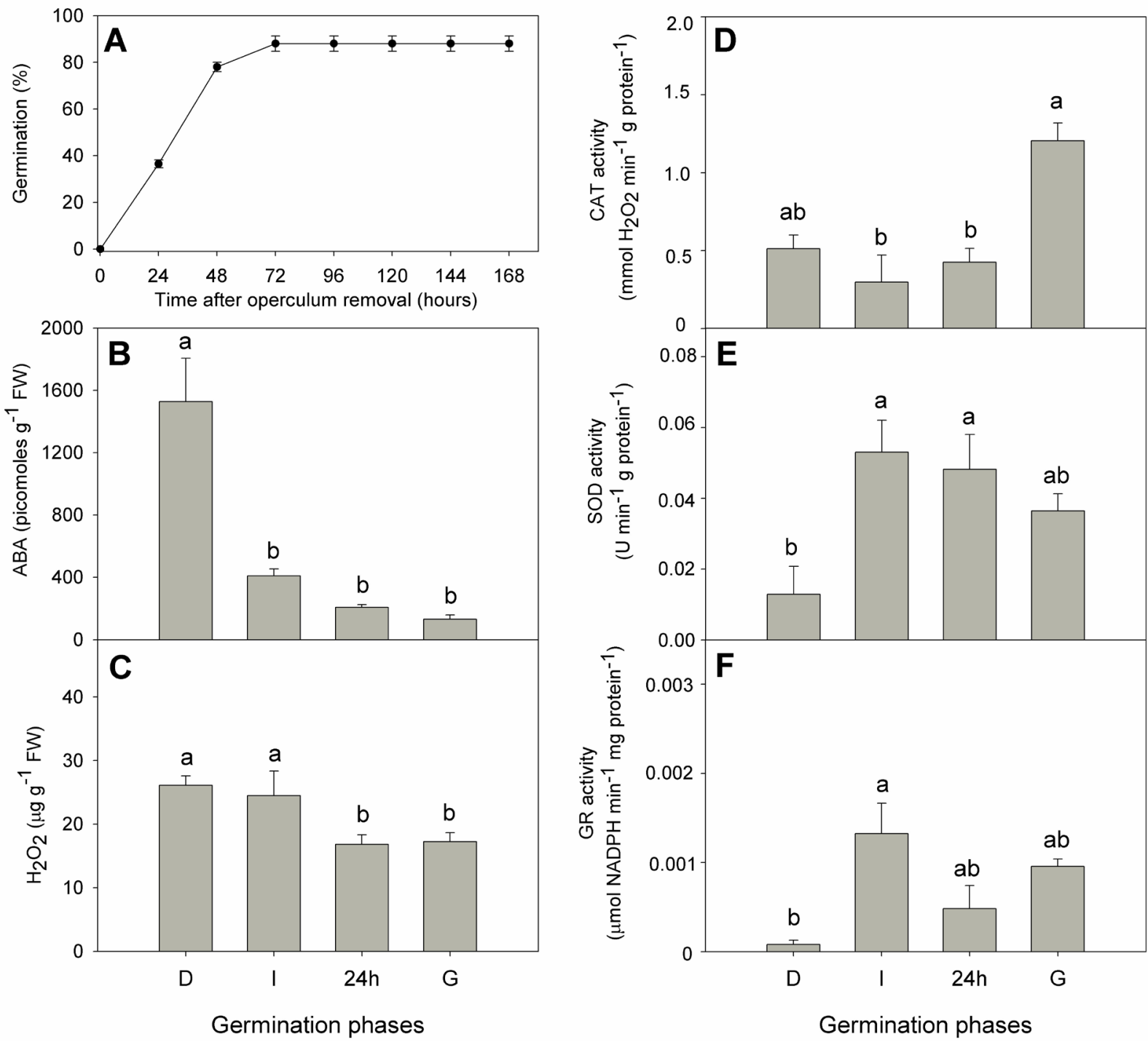

Figure 1. Germination percentage and biochemical parameters for embryos of Butia capitata during phases of germination. Graphics show germination percentage from the dormancy-breaking process $(\mathbf{A})$; levels of ABA (B) and $\mathrm{H}_{2} \mathrm{O}_{2}(\mathbf{C})$; and CAT (D), SOD (E) and GR (F) activities during germination phases. Dots or bars are means \pm standard error of four replicates. Means followed by the same letters do not differ according to Tukey test at $5 \%$ of probability. ABA, abscisic acid; $\mathrm{H}_{2} \mathrm{O}_{2}$, hydrogen peroxide; CAT, catalase; SOD, superoxide dismutase; GR, glutathione reductase (y-axis); D, dry; I, imbibed; 24h, 24 hours after operculum removal; G, early-germinated (x-axis).

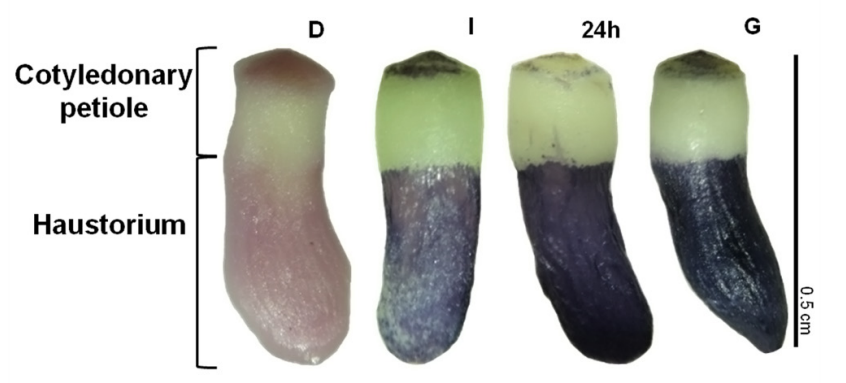

Figure 2. Histolocalization of superoxide anions $\left(\mathrm{O}_{2}{ }^{-}\right)$in embryos of Butia capitata seeds during germination. The dark blue/purple indicates the presence of the anion. D, dry; I, imbibed; $24 \mathrm{~h}, 24$ hours after operculum removal; $G$, early-germinated.
ROS under control during the recovery of metabolism, and thus allowing germination to occur.

The present study showed the involvement of ROS and antioxidant enzymes other than ABA during the germination process of the palm species Butia capitata. The involvement of $\mathrm{H}_{2} \mathrm{O}_{2}$ and $\mathrm{O}_{2}$ - during the entire process was evident. Interestingly, it seems that superoxide anion is more related to germination signaling in B. capitata seeds than the expected $\mathrm{H}_{2} \mathrm{O}_{2}$, by interacting with $\mathrm{ABA}$ after operculum removal and allowing germination itself to proceed. The activity of GR and SOD had important roles in ROS scavenging during the entire process, while CAT activity must be related to the initial development of seedlings due to its increased activity in early-germination 
seeds, as shown here. Taking all the enzymes together, their role in ROS scavenging seems to be secondary to their role in seed germination signalling. The marked presence of $\mathrm{O}_{2}{ }^{-}$was essential for demonstrating that the haustorium is important for palm seed germination from the beginning of the germination process. Actually, the role of the haustorium during palm seed germination itself has been neglected in previous works and needs to be investigated more deeply in B. capitata and in other palm species.

\section{Acknowledgements}

We thank to Prof. LV Modolo for equipment using and to Prof. MP Gomes for critical reading the manuscript. Financial support was provided by CNPq (Conselho Nacional de Desenvolvimento Científico e Tecnológico, 446346/2014-4) and FAPEMIG (Fundação de Amparo à Pesquisa do Estado de Minas Gerais, PPM-00163-16). EM Bicalho received a postdoctoral scholarship from CAPES (Coordenação de Aperfeiçoamento de Pessoal de Nível Superior); TRS Santos was granted a scholarship from CNPq; QS Garcia received a research productivity scholarship from $\mathrm{CNPq}$.

\section{References}

Aebi H. 1984. [13] Catalase in vitro. In: Packer L. (ed.) Methods in enzymology. San Diego, San Diego Academic Press. p. 121-126.

Alvares CA, Stape JL, Sentelhas PC, Gonçalves JLM, Sparovek G. 2013. Köppen's climate classification map for Brazil. Meteorologische Zeitschrift 22: 711-728.

Bailly C. 2004. Active oxygen species and antioxidants in seed biology. Seed Science Research 14: 93-107.

Barba-Espin G, Diaz-Vivancos P, Clemente-Moreno MJ, et al. 2010. Interaction between hydrogen peroxide and plant hormones during germination and the early growth of pea seedlings. Plant, Cell \& Environment 33: 981-994.

Baskin CC, Baskin JM. 2014. Seeds: ecology, biogeography, and evolution of dormancy and germination. San Diego, Academic Press.

Baskin JM, Baskin CC. 2013. What kind of seed dormancy might palms have? Seed Science Research 24: 17-22.

Bewley JD, Bradford KJ, Hilhorst HWM, Nonogaki H. 2013. Seeds: physiology of development, germination and dormancy. New York, Springer.

Bicalho EM, Motoike SY, Borges EEL, Ataíde GM, Guimarães VM. 2016. Enzyme activity and reserve mobilization during macaw palm (Acrocomia aculeata) seed germination. Acta Botanica Brasilica 30: 437-444.

Bicalho EM, Pintó-Marijuan M, Morales M, Müller M, Munné-Bosch S, Garcia QS. 2015. Control of macaw palm seed germination by the gibberellin/abscisic acid balance. Plant Biology 17: 990-996.

Bradford MM. 1976. A rapid and sensitive method for the quantitation of microgram quantities of protein utilizing the principle of protein-dye binding. Analytical Biochemistry 72: 248-254.

Bray EA. 1997. Plant responses to water deficit. Trends in Plant Science 2: $48-54$.

Dias DS, Ribeiro LM, Lopes PSN, Munné-Bosch S, Garcia QS. 2017. Hormonal profile and the role of cell expansion in the germination control of Cerrado biome palm seeds. Plant Physiology and Biochemistry 118: 168-177.

Diaz-Vivancos P, Barba-Espín G, Hernández JA. 2013. Elucidating hormonal/ROS networks during seed germination: insights and perspectives. Plant Cell Reports 32: 1491-502.

El-Maarouf-Bouteau H, Bailly C. 2008. Oxidative signaling in seed germination and dormancy. Plant Signaling \& Behavior 3: 175-182.

Fior CS, Rodrigues LR, Leonhardt C, Schwarz SF. 2011. Overcoming dormancy in seeds of Butia capitata. Ciência Rural 41: 1150-1153.

Foyer CH, Halliwell B. 1976. The presence of glutathione and glutathione reductase in chloroplasts: A proposed role in ascorbic acid metabolism. Planta 133: 21-25.

Foyer CH, Noctor G. 2005. Redox homeostasis and antioxidant signaling: a metabolic interface between stress perception and physiological responses. The Plant Cell 17: 1866-1875.

Giannopolitis CN, Ries SK. 1977. Superoxide dismutases: I. Occurrence in higher plants. Plant Physiology 59: 309-314.

Gomes MP, Carneiro MMLC, Nogueira COG, Soares AM, Garcia QS. 2013. The system modulating ROS content in germinating seeds of two Brazilian savanna tree species exposed to As and Zn. Acta Physiologiae Plantarum 35: 1011-1022.

Gomes MP, Garcia QS. 2013. Reactive oxygen species and seed germination. Biologia 68: 351-357.

Köppen W. 1900. Versuch einer Klassifikation der Klimate, vorzugsweise nach ihren Beziehungen zur Pflanzenwelt. Geographische Zeitschrift 6: 593-611.

Liu F, Jensen CR, Andersen MN. 2005. A review of drought adaptation in crop plants: changes in vegetative and reproductive physiology induced by ABA-based chemical signals. Australian Journal of Agricultural Research 56: 1245-1252.

Liu Y, Ye N, Liu R, Chen M, Zhang J. 2010. H2O2 mediates the regulation of ABA catabolism and GA biosynthesis in Arabidopsis seed dormancy and germination. Journal of Experimental Botany 61: 2979-2990.

Oliveira NCC, Lopes PSN, Ribeiro LM, Mercandante-Simões MO, Oliveira LAA, Silvério FO. 2013. Seed structure, germination, and reserve mobilization in Butia capitata (Arecaceae). Trees 27: 1633-1645.

Oracz K, Voegele A, Tarkowská D, et al. 2012. Myrigalone A inhibits Lepidium sativum seed germination by interference with gibberellin metabolism and apoplastic superoxide production required for embryo extension growth and endosperm rupture. Plant and Cell Physiology 53: 81-95.

Pérez HE, Shiels AB, Zaleski HM, Drake DR. 2008. Germination after simulated rat damage in seeds of two endemic Hawaiian palm species. Journal of Tropical Ecology 24: 555-558.

Segovia AO, Batis AI, Arechiga MR, Mendoza A. 2003. Seed biology of palms: a review. Palms 47: 79-94.

Spera MRN, Cunha R, Teixeira JB. 2001. Quebra de dormência, viabilidade e conservação de sementes de buriti (Mauritia flexuosa). Pesquisa Agropecuária Brasileira 36: 1567-1572.

Svenning JC. 2001. On the role of microenvironmental heterogeneity in the ecology and diversification of neotropical rain-forest palms (Arecaceae). The Botanical Review 67: 1-53.

Tomlinson PB. 2006. The uniqueness of palms. Botanical Journal of the Linnean Society 151: 5-14.

Velikova V, Yordanov I, Edreva A. 2000. Oxidative stress and some antioxidant systems in acid rain-treated bean plants: Protective role of exogenous polyamines. Plant Science 151: 59-66.

Vieira BC, Bicalho EM, Munné-Bosch S, Garcia QS. 2017. Abscisic acid regulates seed germination of Vellozia species in response to temperature. Plant Biology 19: 211-2016.

Weiler EW. 1980. Radioimmunoassays for the differential and direct analysis of free and conjugated abscisic acid in plant extracts. Planta 148: 262-272. 